\title{
REALTIME NOTIFICATION PADA APLIKASI BERBASIS WEB MENGGUNAKAN FIREBASE CLOUD MESSAGING (FCM)
}

\author{
Ahmad Faisol ${ }^{1}$, Febi Rahmadianto ${ }^{2}$ \\ 1) Teknik Informatika, Institut Teknologi Nasional Malang \\ 2) Teknik Mesin, Institut Teknologi Nasional Malang \\ mzfais@gmail.com
}

\begin{abstract}
ABSTRAK
Perkembangan teknologi pada aplikasi berbasis web saat ini dituntut untuk selalu memberikan pelayanan secara realtime. Salah satu bentuk layanan web yang lagi tren adalah pengiriman notifikasi kepada client. Dengan fitur tersebut, sebuah aplikasi berbasis web dapat mengirimkan pemberitahuan tentang berita-berita terbaru atau informasi penting kepada pelanggan melalui media browser. Firebase Cloud Messaging (FCM) merupakan salah satu bentuk layanan yang disediakan oleh Google untuk mengirimkan sebuah pesan atau pemberitahuan kepada pelanggan melalui media browser maupun smartphone. Pada penelitian ini, penulis menerapkan FCM pada Sistem Manajemen Surat (SANES) yang akan mengirimkan pemberitahuan kepada pengguna layanan jika terdapat surat masuk maupun disposisi dari pimpinan. Dengan penerapan FCM ini, diharapkan pengguna aplikasi SANES dapat menerima informasi penting tanpa terbatas oleh waktu dan tempat selama pengguna tersebut memiliki akses dengan perangkat yang terhubung ke internet. Berdasarkan hasil pengujian fungsional, sistem dapat mengirimkan notifikasi selama browser dalam keadaan aktif dan terhubung dengan internet meskipun tanpa mengakses aplikasi. Selain itu, layanan FCM ini dapat berfungsi lebih optimal pada aplikasi yang diakses melalui jalur HTTPS yang valid. Sedangkan berdasarkan hasil pengujian browser, pengiriman notifikasi dengan FCM hanya bisa dilakukan pada browser di lintas platform yang sudah mendukung teknologi Push API.
\end{abstract}

Keyword : firebase cloud messaging, realtime notification, sistem manajemen surat

\section{PENDAHULUAN}

Salah satu kegiatan rutin dari suatu lembaga adalah kegiatan surat menyurat. Setiap surat yang diterima maupun dikirim oleh lembaga jumlahnya tidak sedikit, sehingga terkadang terkendala dalam mengelola arsip dari surat-surat tersebut. Kendala lain yang sering dihadapi adalah surat masuk yang tidak dapat disampaikan kepada tujuan secara cepat karena alasan penerima yang tidak ada di kantor. Sehingga pihak administrasi tidak bisa memberikan jawaban atau menindak lanjuti secara cepat.

Sudah banyak aplikasi administrasi yang dikembangkan untuk mengelola dokumen surat. Akan tetapi aplikasi tersebut masih belum memiliki fitur notifikasi sebagai pengingat atau pengirim pesan kepada pihak terkait. Kekurangan tersebut menyebabkan tindak lanjut terhadap surat masuk dan proses disposisi menjadi terlambat. Salah satu fitur pengirim pesan yang dapat diterapkan sebagai pengingat adalah SMS Gateway. Akan tetapi untuk jangka panjang fitur tersebut membutuhkan biaya yang tidak sedikit karena harus mengeluarkan biaya pulsa tiap SMS.

Melihat betapa pentingnya fitur notifikasi tersebut, maka pada penelitian ini, penulis menentukan untuk menggunakan salah satu layanan pengirim notifikasi yang disediakan oleh Google, yaitu Firebase Cloud Messaging (FCM). Dikutip dari website resmi Firebase, bahwa FCM adalah solusi pengiriman pesan lintas platform yang memungkinkan seorang pengguna mengirimkan pesan dengan terpercaya tanpa biaya (Google Developer, 2016).
Dengan memanfaatkan FCM pada sistem manajemen surat, aplikasi dapat mengirimkan notifikasi secara realtime kepada pihak terkait jika terdapat surat yang harus segera ditindak lanjuti.

\section{TINJAUAN PUSTAKA}

\subsection{Surat}

Surat adalah alat komunikasi tertulis yang berasal dari satu pihak dan ditujukan kepada pihak lain untuk menyampaikan warta (Barthos, 2003). Sedangkan menurut Gie (2000), surat adalah setiap bentuk catatan tertulis atau bergambar yang memuat keterangan mengenai sesuatu hal atau peristiwa yang dibuat orang untuk membantu ingatannya.

Akan tetapi dibandingkan alat komunikasi yang lain surat memiliki kelebihan tersendiri, hal ini dikarenakan surat merupakan sarana yang dapat merekam informasi jauh lebih panjang, lebih rinci namun tetap praktis dan ekonomis. Dalam hal ini surat bersifat praktis yang artinya dapat menyimpan rahasia, efektif artinya sesuai dengan keadaan yang sebenarnya dan ekonomis artinya biaya pembuatan, peralatan dan pengirimannya murah. Dari beberapa penjelasan diatas maka dapat ditarik kesimpulan bahwa surat adalah alat komunikasi yang berisi informasi baik tertulis maupun bergambar yang hendak disampaikan kepada pihak lain yang bersangkutan dan memiliki kelebihan tersendiri dalam hal kerahasiaan, keefektifan dan ekonomis. Jadi dari beberapa pengertian di atas dapat disimpulkan bahwa surat adalah alat komunikasi yang secara tertulis untuk menyampaikan informasi. 


\subsection{Surat Masuk}

Surat masuk adalah surat yang diterima dari perusahaan atau instansi lain kepada pihak yang bersangkutan. Surat masuk merupakan saran komunikasi tertulis yang diterima dari instansi atau perorangan. Dapat pula diartikan, surat masuk adalah semua jenis surat yang diterima dari instansi lain maupun perorangan, baik yang diterima melalui pos maupun yang diterima dari kurir dengan mempergunakan buku pengiriman (Wursanto, 1991).

Pengendalian dan pengurusan surat masuk dalam instansi dapat digolongkan menurut penggolongan jenis surat yaitu (Wursanto, 1991):

1. Surat penting Semua surat yang mengemukakan semua masalah-masalah pokok yang memepengaruhi langsung ataupun tidak langsung, berhasil tidaknya pencapaian tujuan organisasi.

2. Surat rutin atau biasa Surat yang tidak tergolong penting, dimana surat-surat tersebut langsung di tindak lanjuti, relatif singkat dan tidak disimpan terlalu lama.

3. Surat rahasia Surat yang harus disampaikan sesegera mingkin kepada pimpinan (orang yang bersangkutan) yang masih dalam keadaan tertutup, sehingga surat tersebut tidak boleh dibuka oleh penerima surat.

4. Surat pribadi Surat yang disimpulkannya tercantum nama pribadi orang yang bersangkutan, walaupun disertai jabatan formalnya.

\subsection{Surat Keluar}

Surat keluar yaitu surat yang dikirim dari pihak baik instansi, organisasi atau perusahaan yang berisi tentang suatu informasi atau data baik itu perintah, pemberitahuan maupun informasi lainnya. Surat keluar adalah surat yang sudah lengkap (bertanggal, bernomor, berstempel dan telah ditandatangani oleh pejabat yang berwenang yang dibuat oleh suatu instansi atau lembaga lain) (Wursanto, 1991).

\subsection{Firebase Cloud Messaging (FCM)}

Firebase Cloud Messaging (FCM) merupakan layanan cross-platform unutk berkirim pesan yang disediakan oleh Google secara gratis. FCM juga menyediakan fungsi untuk melakukan push notification, yaitu notifikasi yang muncul di bagian atas layar smartphone dan dapat diseret ke bawah, untuk mengakses pesan lengkapnya pengguna cukup menekan pesan yang tampil pada notifikasinya. Penggunaan Fitur push notification dengan FCM sangat membantu karena FCM akan mengirimkan notifikasi secara realtime (Google Developer, 2016). Proses pengirman pesan notifikasi dari aplikasi melalui FCM ke perangkat klien dapat dilihat pada Gambar 1.

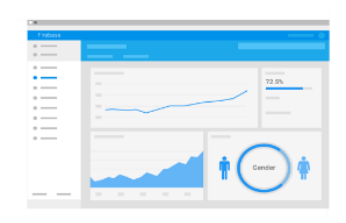

Notifications Console GUI

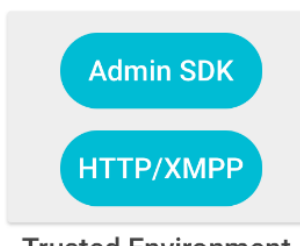

Trusted Environment

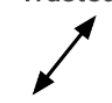

\section{Firebase \\ Cloud Messaging}

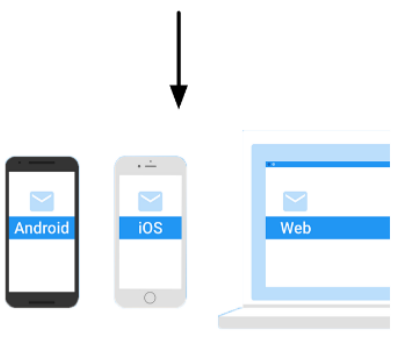

Gambar 1. Proses Pengiriman Notifikasi FCM

\section{METODOLOGI PENELITIAN \\ 3.1 Metode Pengumpulan Data}

Data merupakan sumber atau bahan mentah yang sangat berharga bagi proses menghasilkan informasi. Oleh sebab itu dalam pengambilan data perlu dilakukan penanganan secara cermat dan hatihati, sehingga data yang diperoleh dapat bermanfaat dan berkualitas. Dalam pengumpulan data penyusun mengunakan metode studi lapangan. Dengan metode ini data-data diperoleh langsung dari sumber yang bersangkutan, dimana peneliti berhadapan langsung dengan obyek yang diteliti, yang dilakukan dengan cara :

a. Survei, yaitu mengumpulkan data dengan terjun langsung dan mencatat secara detil tentang obyek permasalahan.

b. Wawancara, yaitu dengan berkomunikasi secara langsung dengan calon pengguna aplikasi.

\subsection{Metode Pengembangan Sistem}

Metode pengembangan sistem yang digunakan adalah sebagai berikut :

1. Analisis dan perancangan sistem

2. Implementasi dan pengujian program

3. Integrasi dan pengujian sistem

Tahap analisis dimulai dengan menganalisis kebutuhan sistem berdasarkan hasil survei dan wawancara serta beberapa literatur tentang sistem manajemen surat dan FCM. Sedangkan perancangan sistem perangkat lunak melibatkan identifikasi dan deskripsi abstraksi sistem perangkat lunak yang terdiri dari proses pembuatan Data Flow Diagram (DFD) dan Use Case Diagram.

Tahap selanjutnya adalah melakukan implementasi hasil perancangan menjadi sebuah 
program yang diakhiri dengan pengujian unit program dan sistem secara keseluruhan. Pengujian fitur notifikasi dilakukan pada browser di lintas platform, baik komputer desktop maupun smartphone.

\section{HASIL DAN PEMBAHASAN}

\subsection{Hasil Implementasi}

Jika terdapat surat masuk, maka bagian administrasi harus memasukkan data surat tersebut ke dalam sistem melalui form input data surat masuk, seperti yang ditunjukkan pada Gambar 2.

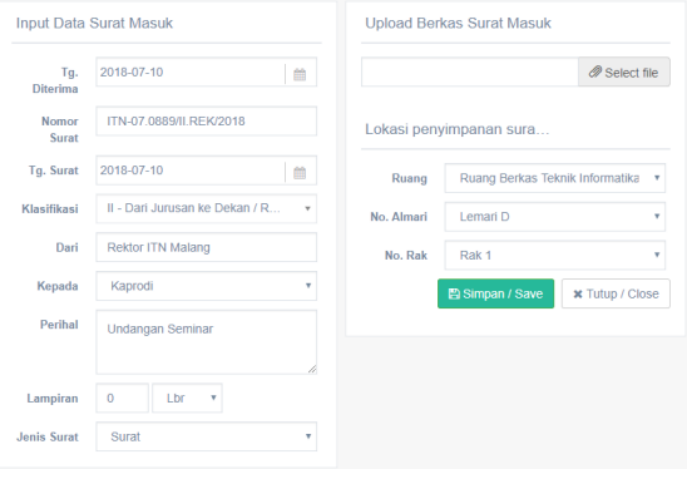

Gambar 2. Halaman Input Data Surat Masuk

Jika terdapat surat keluar yang akan dikirimkan ke unit lain, dapat diinputkan melalui halaman input data surat keluar seperti yang ditunjukkan pada Gambar 3.

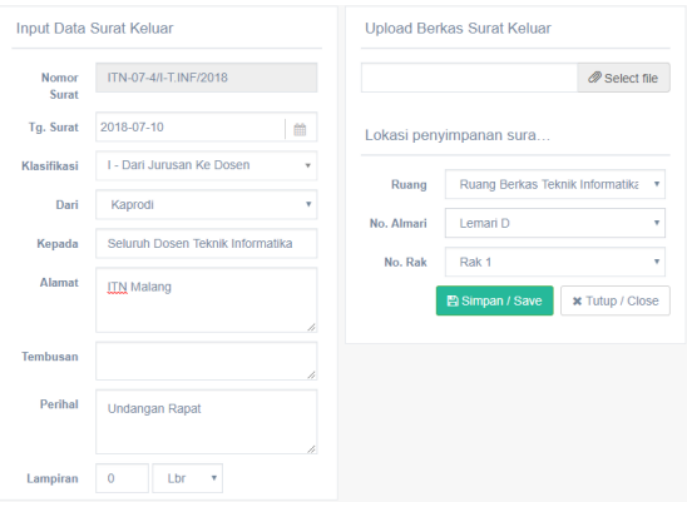

Gambar 3. Halaman Input Data Surat Keluar

Setiap data surat masuk diinputkan oleh administrasi, sistem akan mengirimkan notifikasi kepada pengguna yang dituju pada surat tersebut. Notifikasi akan ditampilkan di bagian pojok kanan bawah pada komputer atau di bagian notifikasi pada smartphone. Contoh tampilan notifikasi dapat dilihat pada Gambar 4 dan 5.

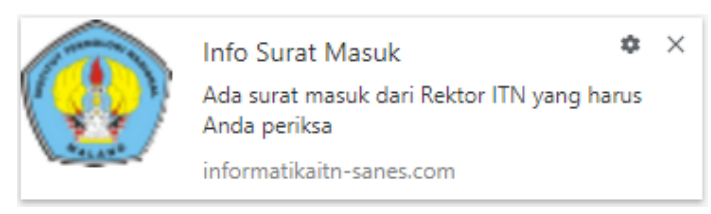

Gambar 4. Tampilan Notifikasi pada computer

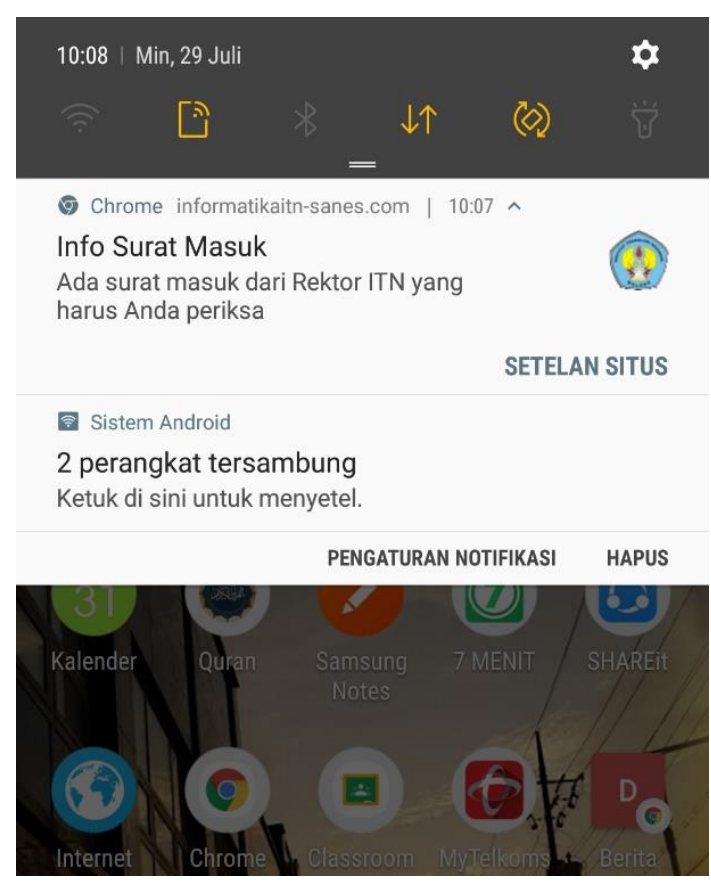

Gambar 5. Tampilan Notifikasi pada Smartphone

\subsection{Pengujian Fungsional}

Pengujian fungsional difokuskan pada pengiriman notifikasi dari aplikasi ke perangkat klien dengan 4 kondisi berbeda menggunakan beberapa browser yang sudah mendukung fitur Push API. Hasil pengujian dapat dilihat pada Tabel 1.

Tabel 1. Hasil pengujian fungsional sistem

\begin{tabular}{|l|c|c|}
\hline \multicolumn{1}{|c|}{ Skenario Pengujian } & $\begin{array}{c}\text { Browser } \\
\text { Komputer }\end{array}$ & $\begin{array}{c}\text { Browser } \\
\text { Smartphone }\end{array}$ \\
\hline $\begin{array}{l}\text { Mengirim notifikasi saat } \\
\text { browser klien ditutup }\end{array}$ & Gagal & Berhasil \\
\hline $\begin{array}{l}\text { Mengirim notifikasi saat } \\
\text { browser klien aktif tanpa } \\
\text { membuka aplikasi }\end{array}$ & Berhasil & Berhasil \\
\hline $\begin{array}{l}\text { Mengirim notifikasi saat } \\
\text { browser klien aktif dan } \\
\text { membuka aplikasi }\end{array}$ & Berhasil & Berhasil \\
\hline $\begin{array}{l}\text { Mengirim notifikasi saat } \\
\text { klien tidak terkoneksi } \\
\text { dengan internet }\end{array}$ & Berhasil & Berhasil \\
\hline
\end{tabular}

Berdasarkan hasil pengujian pada Tabel 1, perangkat klien dapat menerima notifikasi jika browser dalam keadaan aktif dan terhubung ke internet. Pada perangkat smartphone, browser akan selalu aktif meskipun ditutup karena memiliki service / layanan yang selalu aktif. Perangkat yang 
tidak terhubung ke internet akan tetap menerima notifikasi setelah perangkat tersebut kembali terhubung ke internet.

Hal ini menunjukkan bahwa penggunaan layanan FCM untuk mengirim notifikasi ke perangkat klien membuat kinerja suatu sistem akan lebih efektif.

\subsection{Pengujian pada protokol jaringan}

Pengujian fitur notifikasi dilakukan pada protokol jaringan HTTP dan HTTPS di beberapa browser yang sudah mendukung fitur Push API. Hasil pengujian dapat dilihat pada Tabel 2.

Tabel 2. Hasil pengujian notifikasi pada Browser

\begin{tabular}{|c|c|c|c|c|}
\hline Skenario Pengujian & 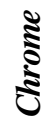 & 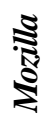 & $\frac{g^{2}}{2}$ & 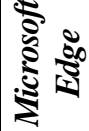 \\
\hline $\begin{array}{l}\text { Permohonan token ID perangkat } \\
\text { (browser) pada jalur http }\end{array}$ & $\begin{array}{l}\overline{\mathscr{G}} \\
\tilde{J}\end{array}$ & 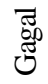 & $\begin{array}{l}\widetilde{6} \\
\text { ]్ర }\end{array}$ & 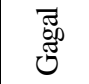 \\
\hline $\begin{array}{l}\text { Permohonan token ID perangkat } \\
\text { (browser) pada jalur https dengan } \\
\text { sertifika yang tidak valid }\end{array}$ & ש్ & 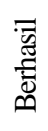 & 苞 & ]్ \\
\hline $\begin{array}{l}\text { Permohonan token ID perangkat } \\
\text { pada jalur https }\end{array}$ & 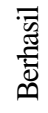 & 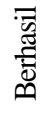 & 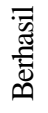 & 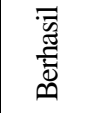 \\
\hline $\begin{array}{l}\text { Pengiriman notifikasi pada jalur } \\
\text { http }\end{array}$ & 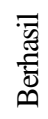 & 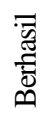 & 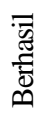 & 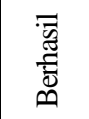 \\
\hline $\begin{array}{l}\text { Pengiriman notifikasi pada jalur } \\
\text { https }\end{array}$ & 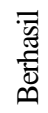 & 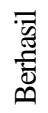 & 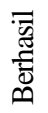 & 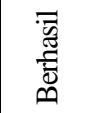 \\
\hline
\end{tabular}

Berdasarkan hasil pengujian pada Tabel 2, dapat dilihat bahwa fitur notifikasi menggunakan FCM lebih optimal pada jalur HTTPS. Hanya browser Mozilla yang masih memberikan ijin untuk mengirimkan permintaan TOKEN ID perangkat dan menerima notifikasi di jalur HTTP. Akan tetapi demi alasan keamanan, lebih tepat jika menggunakan protokol HTTPS pada sistem.

\section{KESIMPULAN DAN SARAN}

5.1. Kesimpulan

1. Dengan menggunakan Firebase Cloud Messaging (FCM) untuk mengirim pesan atau notifikasi secara realtime kepada perangkat klien, kinerja sistem manajemen surat dapat lebih efektif dan efisien.

2. Sistem dapat mengirimkan notifikasi pada perangkat klien selama browser dalam keadaan aktif dan terhubung dengan internet meskipun tanpa mengakses aplikasi.

3. Penggunaan layanan FCM untuk mengirim notifikasi dapat berjalan lancar dan lebih optimal pada aplikasi yang menggunakan protokol HTTPS daripada HTTP.

\subsection{Saran}

1. Diharapkan bagi pengembang aplikasi yang memanfaatkan layanan FCM agar menggunakan protokol HTTPS dengan membeli SSL yang valid.

2. Sistem manajemen surat dapat dikembangkan menjadi aplikasi di beberapa platform, seperti Android dan IOS.

\section{DAFTAR PUSTAKA}

[1]. Aprianijaya, Risma. 2012. Analisa Sistem Manajemen Administrasi Surat di Badan Perpustakaan dan Kearsipan Daerah Provinsi Jawa Barat. Universitas Padjadjaran. Jawa Barat

[2]. Barthos, Basir. 2003. Manajemen Kearsipan. Jakarta: Bumi Aksara

[3]. Developer, Google. 2015. Firebase Cloud Messaging. [online]. Tersedia di: https://firebase.google.com/docs/cloudmessaging/?hl=id [diakses tanggal 20 Januari 2018].

[4]. Gie, The Liang. 2000. Administrasi Perkantoran. Yokyakarta: Modern Liberty

[5]. Masykur, Fauzan. 2015. Sistem Administrasi Pengelolaan Arsip Surat Masuk Dan Surat Keluar Berbasis Web. Universitas Muhammadiyah Ponorogo, Ponorogo

[6]. Wursanto. 1991. Kearsipan 1. Yogyakarta: Kanisius Yogyakarta. 